\title{
Post-mortem Examination of Genital Organs from Sows with Reproductive Disturbances in a Sow-pool
}

\author{
By A.-M. Dalin ${ }^{l}, K$. Gidlund ${ }^{I^{*}}$ and L. Eliasson-Selling ${ }^{2}$
}

${ }^{1}$ Department of Obstetrics and Gynaecology, Faculty of Veterinary Medicine, Swedish University of Agricultural Sciences, Uppsala, and ${ }^{2}$ Swedish Animal Health Service, Uppsala, Sweden.

\begin{abstract}
Dalin, A.-M., K. Gridlund, L. Eliasson-Selling: Post mortem examination of genital organs from sows with reproductive disturbances in a sow-pool. Acta vet. scand. 1997, 253-262. - Over a period of approx. 15 months, post-mortem (PM) examinations were made on genital organs ( 34 gilts and 81 sows) from a sow-pool with reproductive disturbances. Anamnestic data on the animals included information about parity number, date of farrowing, dates of weaning, oestrus and service, and cause of culling. At the PM examination, the macroscopic appearance of the ovaries (follicles, corpora lutea, cysts) and uterus (content, endometrium) were studied. Specimens from the endometrium was examined histologically.

The most common reason for culling was repeat breeding (67\%), in most cases at irregular intervals. The non-productive period averaged 82 days in sows (weaning to slaughter) and 151 days in gilts (from 1st day of mating until slaughter). In $49.6 \%$ of the sows no pathological changes were found. Macroscopic examination of the ovaries in 108 animals showed that $69 \%$ were cycling normally, $17 \%$ were anoestral and $14 \%$ had multiple follicular cysts ( 7 animals were not included due to ovo-testis [1 case], pregnancy [ 3 cases] and with signs of recent abortion [ 3 cases]). As judged from the histological examination, $27 \%$ of the animals had endometritis, which was classified as mild in $50 \%$ of them. Anoestral animals had a higher incidence of endometritis (61\%) than animals showing cyclic ovarian activity (19\%). This indicates that ovarian inactivity is of importance for the development of endometritis.

It was concluded that post-mortem examination of genital organs from animals with reproductive problems is a valuable diagnostic tool. The anamnestic data together with the PM results indicated that management routines (oestrous detection, insemination, grouping at early pregnancy) needed to be changed.
\end{abstract}

orary, uterus.

\section{Introduction}

The Swedish sow-pool system was started in 1988. The main aims were to produce piglets in batch farrowing and to create a strict age-segregated system designed to protect the health of the piglets. A sow pool, SP, consists of a central unit and satellite herds. The sows are kept in the central unit during the dry period, i.e. from weaning, through mating and pregnancy, until 3 weeks before farrowing, when they are transported to satellite herds, in most cases within a distance of $40 \mathrm{~km}$. The sows stay in the satellite herd during farrowing and lactation, altogether 8 weeks, and at weaning they are transported back to the central unit. The piglets are raised in the satellite herds until they reach a weight of about $25 \mathrm{~kg}$, when they are sold to other farms 
for production of slaughter pigs. A few satellite herds have integrated production (Holmgren \& Gerth Löfstedt 1993, Löfstedt 1994).

Today approximately $15 \%$ of the Swedish sows are included in 31 SP (Robertsson 1996). This represents a sharp increase from the 13 herds existing at the beginning of 1993. The sow-pool system implied radical changes in sow management; for example, in addition to being transported, the sows are placed in mixed and often large groups. The mean number of sows weaned every one or 2 weeks varies between 50 and 90 , which means that approximately 60 sows arrive and are mixed in the reception/mating area at a central unit each time (EliassonSelling et al. 1994). As a consequence, oestrous detection and insemination have to be carried out on large groups of sows at the same time.

In 1993, reproductive disturbances were a very common problem according to the Swedish Animal Health Service. The causes were multifactorial; however, strict and careful management routines concerning reproduction improved the production results (Eliasson-Selling et al. 1994).

The present study describes reproductive problems in a SP with 1700 sows and 19 satellite herds. The reproductive problems, especially repeat breeding, culminated 6-8 months after start. The reproductive problems were investigated by the Swedish Animal Health Service. Post-mortem examinations of the genital organs were used as a diagnostic tool. Furthermore, to get a deeper understanding of reproduction in SP's as a whole, post-mortem screening of sows culled due to reproductive failure was continued also when the reproductive results of the SP had been normalised.

The aim of this study was to analyse the data from the post-mortem examinations of genital organs from sows culled due to reproductive failure in a SP.

\section{Materials and methods}

Post-mortem (PM) examinations were done on 115 genital organs from female animals showing reproductive failure in a SP. The animals consisted of 34 gilts and 81 sows of crossbred (Swedish Landrace $\times$ Swedish Yorkshire) breed. The PM examinations were performed for approx. 15 months (August 1993 until October 1994, Table 2) and included 2 periods [AugustOctober 1993, (period 1) and October 1994 (period 5)], when the reproductive results of the SP central unit were unacceptably low. The herd manager was instructed to send all sows with reproductive failure for PM examination. However, information on the total culling rate of gilts and sows was not available for the particular SP studied. Therefore it was not possible to know exactly how many of the total number of gilts and sows with reproductive failure had actually been PM-examined.

\section{Management}

During the studied period the SP transported 160 sows every week: 80 sows were transported to satellites, and 80 sows from satellites arrived at the reception/mating area, with deep straw bedding in the central unit. In the mating area the sows were mixed in groups of up to 50 individuals and fed twice daily with a liquid diet (12 MJ, 13 C.P.) based on barley and whey. They were fed individually, according to appetite, from weaning to oestrus and thereafter regrouped with an allowance of $2.2 \mathrm{~kg}$ per day. After insemination the sows were regrouped and moved to long, narrow pens, with 18 sows per pen. In these pens the sows were group-fed in troughs without trough dividers. Pregnancy was tested with "Pregtone ${ }^{\circledR}$ " equipment after approximately 4 weeks. Pigs were routinely vaccinated against porcine parvovirus infection and erysipelas, twice before first mating, and revaccinated twice a year. 


\section{PM examination}

The sows subjected to PM examination were individually marked at the SP central unit and slaughtered at the same slaughterhouse. The post-mortem examinations were performed at the Department of Obstetrics and Gynaecology within $24 \mathrm{~h}$ after slaughter. The anamnestic data on the animals comprised the following information: identity, parity number, dates of farrowing, weaning, oestrus and service, and cause of culling.

For repeat breeders, the regularity of the oestrous cycles was estimated based on the information about the 2 latest inseminations and/or following oestrous symptoms. The oestrous cycle was considered to be irregular when it was $\geq 25$ days (Dial et al. 1992).

The number of non-productive days, i.e. days when the animals were neither lactating nor in gestation, was calculated in the sows from weaning until culling and in gilts from the first insemination/mating until culling.

At the PM examination, the macroscopic appearance of the ovaries (follicles, corpora lutea, cysts) and uterus (content, endometrium) was investigated. In addition, the ovaries and uterus were weighed, the follicles and corpora lutea were measured, and the stage of oestrous cycle was estimated. The total number of corpora lutea was also recorded. From the macroscopic appearence of the ovaries, the animals were classified as anoestral (no corpora lutea), oestral - i.e. ovarian cyclicity (either corpora lutea when in dioestrus or mature follicles when in an oestrous stage), or cystic (formation of multiple follicular cysts, $\geq 1.5 \mathrm{~cm}$ in diameter). The oviducts and bursae ovaricae were inspected as well as the bladder and the caudal (vagina and vest. vagina) and external parts of the genital organs.

Specimens $(0.5 \times 1 \mathrm{~cm})$ were taken from at least 2 sites on the uterine wall for light microscopy. Tissue pieces were fixed in formalin solution
$(10 \%)$, dehydrated and embedded in paraffin, and finally stained with hematoxylin-eosin (HE). The endometrium was given a histological examination, including an estimation of the stage of the oestrous cycle and the extent of infiltration of leucocytes, i.e. inflammatory reaction. A four-grade scale was used for classification: normal endometrium and slight, moderate or severe endometritis (cf. Karlberg et al. 1981). All examinations were done by the same investigator. The classification was based on the amount and type of leucocyte infiltration and changes in the endometrium. The interpretation was carried out considering the stage of the oestrous cycle, because around and during oestrus a slight increase in the abundance of neutrophilic granulocytes and lymphocytes in the subepithelial layer can normally be seen (Leiser et al. 1988).

Samples for bacteriological examination were taken from the uterus and/or bladder only in cases where macroscopic observations indicated the existence of infections.

Statistical analyses were performed using the Statistical Analysis System version of Fischer's exact test (SAS Institute Inc.) and a T-test (Stat Graph).

\section{Results \\ Reproductive data}

Anamnestic data on reason for culling for 115 animals are summarised in Table 1. Of the slaughtered animals, $70.5 \%$ were gilts or first parity sows. The most common reason for culling was repeat breeding $(67 \%)$, followed by "no pregnancy" (11\%) and "no oestrus" $(10 \%)$. The only significant difference between parity groups with regard to the reason for culling concerned the frequencies of "not pregnant" and "abnormal oestrous behaviour" $(p<0.05)$. Due to the lack of information about the total number of culled sows in the SP, no information 
Table 1. Reason for culling, parity and number of animals.

\begin{tabular}{|c|c|c|c|c|c|c|}
\hline \multirow{2}{*}{ Reason for culling } & \multicolumn{4}{|c|}{ Parity number } & \multicolumn{2}{|c|}{ Total } \\
\hline & 0 & 1 & 2 & $\geq 3^{* *}$ & Number & $\%$ \\
\hline Repeat breeding & 27 & 28 & 11 & 11 & 77 & 67.0 \\
\hline No oestrus & 3 & 7 & 2 & 0 & 12 & 10.4 \\
\hline Not pregnant & 0 & 8 & 2 & 3 & 13 & 11.3 \\
\hline Discharge & 1 & 2 & 0 & 1 & 4 & 3.5 \\
\hline Abortion & 3 & 1 & 0 & 0 & 4 & 3.5 \\
\hline Abnorm. behaviour* & 0 & 1 & 1 & 3 & 5 & 4.5 \\
\hline Total , number & 34 & 47 & 16 & 18 & 115 & 100 \\
\hline Total, \% & 29.6 & 40.9 & 13.9 & 15.6 & 100 & \\
\hline
\end{tabular}

* Abnormaly long oestrous behaviour.

** The number of sows for parity 3,4 and 5 were 12,5 and 1 , respectively.

on the total culling rate during this period can be presented.

Based on the anamnestic information it was possible to calculate repeat breeding intervals for 72 of the 77 animals. Repeat breeding at irregular intervals was much more common than repeat breeding at regular intervals, the incidence being $76 \%$ and $24 \%$ for the irregular and regular intervals, respectively. No significant difference in repeat breeding regularity was found between parity groups.

Table 2 shows the temporal distribution of culling and reasons for culling during the 15 -month period. Approximately $50 \%$ of the total number of examined animals were slaughtered during the first period, August-October 1993, and repeat breeding $(38 / 57)$ was the dominating problem.

The non-productive period, defined in sows as the period from weaning to culling, averaged 82 days for all sows. For culled sows in the "repeat breeder", "no oestrus", and "not pregnant" categories, the mean non-productive period lasted an average of 102 days (range 37-219 days), 42 days (29-67 days), and 58 days (38-101 days), respectively. For 28 of the gilts the mean number of non-productive days, calculated as the period from first insemination/mating until

Table 2. Reason for culling, distributed over the 15-month period.

\begin{tabular}{|c|c|c|c|c|c|c|}
\hline \multirow{2}{*}{ Reason for culling } & \multicolumn{6}{|c|}{ Three-month periods } \\
\hline & 1 (Aug-Oct) & 2 (Nov-Jan) & 3 (Feb-Apr) & 4 (May-Jul) & 5 (Aug-Oct) & Tot. no \\
\hline Repeated breeding & 38 & 13 & 6 & 8 & 12 & 77 \\
\hline No oestrus & 8 & 0 & 2 & 2 & 0 & 12 \\
\hline Not pregnant & 7 & 0 & 0 & 2 & 4 & 13 \\
\hline Discharge & 0 & 1 & 0 & 2 & 1 & 4 \\
\hline Abortion & 4 & 0 & 0 & 0 & 0 & 4 \\
\hline Abnorm. behaviour* & 0 & 0 & 0 & 2 & 3 & 5 \\
\hline Total no & 57 & 14 & 8 & 16 & 20 & 115 \\
\hline
\end{tabular}

* abnormally long oestrous behaviour. 
Table 3. Ovarian activity (anoestral, oestral and cystic sows), based on macroscopic appearance, in relation to anamnestic data on reason for culling.

\begin{tabular}{lccc}
\hline Reason for culling & Anoestral animals, no. & Oestral animals, no. & Cystic animals, no. \\
\hline Repeat breed. & 8 & 58 & 9 \\
No oestrous & 7 & 5 & 0 \\
Not pregnant & 2 & 9 & 2 \\
Abnorm. behaviour* & 0 & 1 & 4 \\
Discharge & 1 & 2 & 0 \\
Total no. & 18 & 75 & 15 \\
\hline
\end{tabular}

* abnormal long oestrous behaviour.

culling, was 151 days (range $71-221$ days). Gilts for which the 1st day of insemination was unknown were excluded.

\section{PM examination}

In $49.6 \%$ of the animals (57/115) no pathological changes or abnormalities were found in the ovaries or uterus. Three of these animals were pregnant, and all others showed normal, cyclic ovarian activity. According to the anamnesia of these 57 animals, $72 \%$ were repeat breeders, $14 \%$ were not pregnant at the time of the pregnancy test, $10 \%$ showed no oestrus, $2 \%$ produced a discharge and $2 \%$ showed abnormal oestrous behaviour.

Table 3 shows the relation between the anamnestic data and the classification according to ovarian activity for 108 gilts ( 3 pregnant gilts, one sow with unilateral ovo-testis, and 3 that had recently aborted were excluded). The majority $(69 \%)$ of the animals had ovaries showing cyclic activity; $17 \%$ of the animals were anoestral, and $14 \%$ had multiple follicular cysts. Five of the animals in which no oestrus was observed were, in fact, oestral and vice versa. Eight of the repeat breeders, which were expected to show cyclic activity, were actually anoestral. Seven of 15 animals with follicular cysts in their ovaries were detected in the 4th period (cf Table 2). Four of the animals with follicular cysts were gilts.
The mean weights of ovaries were $5.2 \mathrm{~g}$ (range 2.8-8.1), $7.6 \mathrm{~g} \mathrm{(2.0-21.1)} \mathrm{and} 40.0 \mathrm{~g}(8.2-88.8$ g) for anoestral (without corpora lutea), oestral (with corpora lutea or mature follicles when slaughtered at oestrus) and cystic ovaries (multiple folliclular cysts), respectively. Ovaries with cysts were significantly heavier $(p<0.001)$ than the other types, and ovaries from animals with an anoestral stage were significantly lighter than ovaries from animals with cyclic activity.

Oestral animals had a mean of 15 (range 8-26) corpora lutea. There was no significant difference between gilts (14, range 8-23) and sows (16, range 10-26). However, there was a significant difference $(\mathrm{p}<0.05)$ between the mean number of corpora lutea in the left (8) and right (7) ovaries when considering all animals.

For anoestral, oestral and cystic animals, the mean uterine weights were $408 \mathrm{~g}$ (range 141$865 \mathrm{~g}$ ), $785 \mathrm{~g}$ (range $380-1530 \mathrm{~g}$ ) and $608 \mathrm{~g} \mathrm{(-}$ range $263-1307 \mathrm{~g}$ ) respectively, with the differences being significant $(\mathrm{p}<0.05)$. There was also a significant difference in uterine weights between oestral gilts (mean weight $691 \mathrm{~g}$ ) and oestral sows (mean weight $817 \mathrm{~g}$ ).

At the histological examination it was found that 29 of 108 animals (27\%) had endometritis. The relation between the degree of endometritis (mild, moderate, severe) and ovarian activity is shown in Table 4. 
Table 4. Degree of endometritis in relation to ovarian activity (anoestral, oestral and cystic formation) in the animals.

\begin{tabular}{lcccc}
\hline & \multicolumn{4}{c}{ Degree of endometritis } \\
\cline { 2 - 5 } Ovarian activity & Mild & Mild - moderate & Moderate & Severe \\
\hline Anoestral & 5 & 1 & 2 & 3 \\
Oestral & 7 & 2 & 3 & 2 \\
Cystic & 3 & 0 & 1 & 0 \\
Total number & 15 & 3 & 6 & 5 \\
\hline
\end{tabular}

Anoestral animals had a much higher incidence of endometritis $(11 / 18,61 \%)$ than oestral ones $(14 / 75,19 \%)$. Approximately $50 \%$ of the affected animals (15/29) had a sparse degree of endometritis, and in most cases the inflammatory cell reaction was dominated by lymphocytes (diffuse infiltration and/or with small aggregates in lamina propria). The 5 animals with severe endometritis had pyometra, and 4 of them had remnants of macerated foetuses. The fifth showed an acute reaction after abortion, with both $E$. coli and Actinopyogenes spp. being isolated from the uterus.

The incidence of endometritis among the culled animals varied from $13 \%$ to $30 \%$ over the study period (Table 5). The incidence tended to be positively related to the frequency of reproductive disturbances in the SP.

Only 4 animals (3.5\%) showed signs of an inflammatory reaction in the bladder. Of these, 3 had a slight cystitis, and one animal had a hemmorhagic cystitis (growth of Actinomyces pyogenes). This sow also showed a moderate degree of endometritis.

\section{Discussion}

Reproductive disturbances, particularly repeat breeding, were the dominating problem in the SP and were also the original reason for the PM examinations. Unfortunately, information on the actual total culling rate during the period studied, irrespective of the reasons, was not available. However, Eliasson-Selling \& Lundeheim (1996) presented a preliminary report on the longevity of sows in 5 other Swedish SP. According to their report, the culling rate was generally $40 \%-50 \%$, and the most important reason for culling was reproductive disturbances (33\%). This finding is in close accordance with other surveys of culling in Swedish sows, in which it was found that approximately $30 \%$ were culled due to reproductive failure (Einarsson \& Settergren 1974, Ringmar Cederberg \& Jonsson 1996). In a review of culling rates in sows which covered 10 countries (D'Allaire \& Drolet 1992) it was found that culling due to reproductive failure varied between $12.9 \%$ and $41.4 \%$. In the present study the dominant reason for culling was repeat breeding (67\%). This figure might, however, be slightly biased since it was not possible to determine how many of the sows with reproductive failure during the period actually had been examined. In any case, when comparing the results in this study with those of others, the level of repeat breeding was very high. Einarsson \& Settergren (1974) reported that in the reproductive-failure group, $14 \%$ of the failures were due to repeat breeding. In another Swedish study on culled sows the corresponding value was $30.5 \%$ (Jonsson, unpublished).

According to the review by D'Allaire \& Drolet (1992), young females are more likely to be 
Table 5. Incidence of endometritis over the 15-month period

\begin{tabular}{lccccc}
\hline Periods & 1 (Aug-Oct) & 2 (Nov- Jan) & 3 (Febr-Apr) & 4 (May-July) & 5 (Aug-Oct) \\
\hline Incidence of endometritis & $28 \%$ & $14 \%$ & $13 \%$ & $19 \%$ & $30 \%$ \\
\hline
\end{tabular}

culled due to reproductive failure than are older sows, which is in accordance with the present findings; i.e. $29.4 \%$ and $40.9 \%$ of the culled animals were gilts and first parity sows, respectively. Einarsson \& Settergren (1974) and Einarsson et al. (1982) reported the incidence among culled first-parity sows to be $26 \%$ and $36 \%$, respectively. Another reason for the high incidence among young sows in this study could be that the SP had recently been established and therefore included few sows with a high parity number.

In this study the mean non-productive period for sows was 82 days. Repeat breeders which had a mean non-productive period of 102 days, were of special interest. Pattison et al. (1980) reported an average of 79 days for sows culled for return in a herd. In Sweden the Animal Health Service recommends that farmers cull sows if they have a second repeated oestrus, which means a non-productive period of approximately 50 days if the returns are in regular time. In this study repeat breeding with irregular returns dominated, which might be the reason for the long period of nonproductivity. Non-productive days are not only very costly in terms of feed and labour, but also result in underutilized production. Furthermore, in an SP system the non-productive days are an extra problem because it is the obligation of the central unit to deliver a specific number of pregnant sows every week to satellites.

Normally, sows with irregular returns should not constitute more than $30 \%$ of the repeat breeders (Dial et al. 1992). In this study, however, the frequency was $76 \%$. Irregular returns may occur if the animals fail to maintain preg- nancy (Dial et al. 1992). One reason for such irregularity appears to be "seasonal effects", as indicated by studies showing that repeat breeders are most common during early autumn (Love et al. 1994) and that group-housed sows are more sensitive to seasonal returns than are individually housed ones (Telfser et al. 1996). Another reason for the irregular returns might be stress due to the regrouping of sows during early pregnancy (see review by Einarsson et al. 1996). In the present study they may also have been management related, e.g. insufficient oestrous detection of sows in large groups, causing an inadequate registration, etc.

In many cases, post-mortem studies on ovarian activity in sows with reproductive failure have dealt with animals culled owing to anoestrus. For example, Einarsson \& Bane (1974), Einarsson et al. (1982) and Karlberg (1979) reported that $42 \%, 45 \%$ and $57 \%$, respectively, of anoestral sows had corpora lutea in their ovaries when examined post mortem. Einarsson et al. (1974) reported that $65 \%$ of anoestral gilts had corpora lutea in their ovaries at slaughter. In the present study ovaries in $42 \%$ of the sows culled due to anoestrus showed cyclic activity. This means that the animals either had a "silent oestrus" or that oestrus detection had been insufficient. One explanation might be that sows ranked low owing to stress show less intense oestrous symptoms when they are grouped together with high-ranked sows (Pedersen et al. 1993). Moreover, in sows grouped after weaning, subordinates showed a significantly higher increase in cortisol compared with higher ranked sows. It is also worth noting that $11 \%$ of the repeat breeders in this study were anoestral. 
One reason for this incorrect observation might be that the system used to register repeat breeders was inadequate.

In the present study the frequency of animals with multiple cysts was in agreement with earlier studies (Karlberg 1979, Einarsson et al. 1982). Karlberg (1979) reported a seasonal difference, i.e. a higher incidence from October until March. In the present study $47 \%$ of the cystic animals were found in May-July, which represent only one fifth of the observation period, thus indicating that seasonal variation in cyst formation may exist. Although ovarian cysts do not usually form in gilts (Karlberg 1979) they were detected in $12 \%$ of the gilts in our study. One reason for this could have been that cortisol levels in the gilts increased in response to environmental stress. This seems plausible since it has been shown that long-term ACTH treatment blocked ovulation and induced follicular cysts (Liptrap 1970, 1973).

The ovulation rate is normally higher in sows (approx. 20 follicles) than in gilts (10-15 follicles). In this study no significant difference was found in the number of corpora lutea between oestral sows and gilts, possibly because the gilts were culled at an "old age". Although no information on gilt age was obtained in the anamnestic survey, the long period from first insemination until culling (151 days) supports this interpretation.

In this study $27 \%$ of the animals had histologically diagnosed endometritis, and among these animals, "slight endometritis" was common. These findings are in agreement with earlier studies on sows culled due to reproductive failure (Karlberg et al. 1981, Einarsson et al. 1982). The endometritis in our study was, in most cases, subclinical, and few (3.5\%) sows were culled due to vaginal discharge. Subclinical endometritis has been diagnosed in sows culled due to repeat breeding (Paredis 1962, Herman et al. 1967, Karlberg et al. 1981) and may be a cause of early embryonic death ( $E i$ narsson 1991). In the present study a much higher frequency of endometritis was found among anoestral animals than among animals showing cyclic ovarian activity. The reason for this is probably that during the oestrous periods in animals with cyclic activity, local immune activity is enhanced in the uterus (Hussein et al. 1983), as are uterine contraction and secretion, which all contribute to cleaning the uterus.

Furthermore, in an experimental study in which the uterus of pubertal, unmated gilts was infected with E. coli, de Winter et al. (1992) showed that the stage of oestrous cycle affects the development of endometritis: Gilts inoculated during oestrus did not contract endometritis, whereas gilts inoculated $12 \mathrm{~h}$ after the end of standing reflex (i.e. during metoestrus) developed the disease. These results show that insemination at an inappropriate time can cause endometritis.

It should be noted that the incidence of endometritis tended to be higher during periods with increased reproductive failure.

In approximately $50 \%$ of the culled animals in this study no pathological changes were found in either the ovaries or uterus. The explanation for this might be multifactorial. Any genital changes might have healed by the time of culling since the sows were held for a long time before they were culled. The mean number of non-productive days was 82 . On the other hand, pathological, genital disturbances might have been of minor importance in comparison with the management-related problems.

\section{Conclusion}

It was concluded that post-mortem examination of genital organs from animals with reproductive problems was a valuable diagnostic tool. The anamnestic data together with the PM result indicated that management routines (oestrous detection, insemination, grouping at early pregnancy) needed to be changed. 


\section{References}

D'Allaire $S$, Drolet $R$ : Culling and mortality in breeding animals. In: Leman $\mathrm{AD}$, Straw BE, Mengelin WL, D'Allaire SD, Taylor DJ, (eds): Diseases of swine, 7th ed. Wolfe Publishing Ltd. 1992, pp. 861-871.

Dial GD, Marsh WE Polson DD, Vaillancourt, JP: Reproductive failure: Differential diagnosis. In: Leman AD, Stra, BE, Mengelin WL, D'Allaire SD, Taylor DJ, (eds): Diseases of swine,7th ed. Wolfe Publishing Ltd. 1992, p. 88-137.

Einarsson S: Subklinisk endometrit hos sugga. Subclinical endometritis in the sow. Proc. Nordisk Mastittt og reproduksjonsmote, Trondheim, 1991, 30-35.

Einarsson S, Bane A: Post mortem examination of genital organs of sows culled for anoestrus or repeat breeding. Proc., 12th Nordic Vet. Congress, Reykjavik, 1974, p. 278.

Einarsson S, Linde C, Settergren I: Studies of genitals organs of gilts culled for anoestrus. Theriogenology, 1974, 2, 109-113.

Einarsson S, Lundeheim N, Martinsson $K$, Persson N, Persson, I: Post mortem examination of the genital organs of culling sows from a large herd with relation to fertility data. Proc. IPVS congress, Mexico, 1982, p. 211.

Einarsson S. Madej A, Tsuma V: The influence of stress on early pregnancy in the pig. Proc. 13th International Congress on Animal Reproduction, Sydney, 1996, 165-172.

Einarsson S, Settergren I: Fruktsamhet och utslagsorsaker i ett antal mellan svenska suggbesättningar. (Sow fertility and sow culling reasons in Swedish herds). Nord. Vet. Med., 1974, 26, 576-584.

Eliasson-Selling L, Holmgren N, Lundeheim N: Inventering av fruktsamheten samt inkapning, djurflöde och djurhäha i svenska suggpooler, hösten 1993. (Fertility data, herd management and animal health in Swedish sow-pools, autumn 1993). Swedish Animal Health Service, S-121 86 Johanneshov, 1994, p. 41.

Eliasson-Selling L, Lundeheim $N$ : Longevity of sows in Swedish sow pools. Proc. NJF seminarium, Foulum, 1996, no 265.

Herman J, Bouters R, Vandeplassche M: Endometirits in the sow. Vlaams Diergeneeskunde Tijds, 1967, 36, 134-141.

Holmgren N, Gerth Löfstedt M: Aktuell utveckling av suggpooler i Sverige. Svensk Vet. Tidn., 1993, $45,111-113$.
Hussein AM, Newby TJ, Bourne FJ: Immunochemical studies of the local immune system in the reproductive tract of the sow. J. of Reprod. Immunology, 1983, 5, 1-15.

Karlberg K: Postmortelle undersøkelser i kønnsorganer fra purker slaktet på grunn av reproduktionsproblemer. (Post-mortem examination of genital organs from sows slaughtered due to reproduction failure). Norsk Veterinaertidskrift, 1979, 91, 731-741.

Karlberg K, Rein KA, Nordstoga K: Histologisk og bakteriologisk undersokelser av uterus fra purker utrangert på grunn av omlop. (Histological and bacteriological examination of uterus from the repeat breeder gilt and sow). Nord. Vet. Med., 1981, 33, 359-365.

Leiser R, Zimmermann W, Sidler, Christen A: Normal-zyklische Erscheinungen in Endometrium und an Ovar des Schweines. (Normal cyclical changes in endometrium and ovaries of sows). Tierärtzl. Prax., 1988, 16, 261-280.

Liptrap RM: Effect of corticotrophin and corticosteroids on oestrus, ovulation and oestrogen excretion in the sow. J. Endocrin., 1970, 47, 197-205.

Liptrap RM: Oestrogen excretion by sows with induced cystic ovarian follicles. Res. Vet. Sci., 1973, 15, 215-219.

Love RJ, Evans G, Kuipiec C: Seasonal effects on fertility in gilts and sows. J. Reprod. Fert., Suppl., 1994, 48, 191-206.

Löfstedt M: Sowpools in Sweden - development and experiences. Proc. XVII Nordic Veterinary Congress, Reykjavik, 1994, 87-90.

Paredis F: Fertility and artificial insemination in pigs. Intern. J. of Fert., 1982, 7, 223-233.

Pattison HD, Cook GL, McKenzie S: A study of culling problem in commersial pig breeding herds. Proc. Br. Soc. Anim. Prod., Harrogate, 1980, pp. 462-463.

Pedersen LJ, Rojkittikhun T, Einarsson S, Edqvist $L E$ : Postweaning grouped sows: effects of aggression on hormonal patterns and oestrous behaviour. Applied Animal Behaviour Science, 1993, 38, 25-39.

Ringmar Cederberg E, Jonsson L: Sow culling in Sweden. Proc. NJF seminarium, Foulum, 1996, no 265.

Robertsson JA: The Swedish erradication programme on Aujezkys disease. Swedish Animal Health Service, 12186 Johanneshov, 1996

Telsfer SL, Love RJ, Evans G: Influence of season and type of housing on plasma growth hormone con- 
centration in early pregnant gilts. Proc.13th Congress on Animal Reproduction, Sydney, 1996, p. 16-18.

de Winter PJJ, Verdonck M, de Kruif A, Devriese LA, Haesebrouck F: Endometritis and vaginal discharge in the sow. Anim. Repr. Sci., 1992, 28, 51-58.

\section{Sammanfattning}

Post mortal undersökning av könsorgan från suggor, utslaktade på grund av reproduktionsstörningar $i$ en suggpool.

Post-mortala undersökningar av könsorgan från sammanlagt 34 gyltor och 81 suggor från en suggpool gjordes under en period av ca. 15 månader. I anamnestiska uppgifter ingick information om kullnummer, grisningsdag, avvänjningsdag, brunst och betäckning/insemination samt orsak till utslagning. I den post-mortala undersökningen ingick makroskopisk undersökning av framförallt ovarier (folliklar, corpora lutea och cystor) samt uterus (innehåll, endometrium). Snitt från uterusväggen undersöktes histologiskt.
Den vanligaste orsaken till utslagning var omlöpningar $(67 \%)$, i de flesta fall med oregelbundet intervall. Den icke produktiva tiden var i medeltal 82 dagar hos suggor (avvänjning till slakt) och 151 dagar hos gyltor (från första insemination/betäckning till slakt). Patologiska förändringar saknades hos $49,6 \%$ av djuren. Den makroskopiska undersökningen visade att 108 djur hade normal cyklicitet, $17 \%$ var anöstrala och $14 \%$ hade multipla follikelcystor (7 djur uteslöts beroende på följande orsaker: ovotestis ( 1 fall), dräktighet ( 3 fall) och nyligen aborterad ( 3 fall)).Den histologiska undersökningen av uterus visade att $27 \%$ av djuren hade endometrit, i hälften av fallen klassificerades den som lindrig. Anöstrala djur hade en högre incidens av endometrit (61\%) än djur som hade cyclisk aktivitet i ovarierna (19\%). Detta indikerar att aktiviteten i ovarierna har betydelse för utvecklingen av endometrit.

Konklusion: Post-mortala undersökningar av könsorgan från djur med reproduktionsstörningar är ett viktigt diagnostiskt hjälpmedel. Anamnes tillsammans med resultatet av den postmortala undersökningen indikerade att skötselrutinerna (brunstkontroll, insemination, gruppering) behövde ändras.

(Received November 20, 1996; accepted May 5, 1997).

Reprints may be obtained from: Anne-Marie Dalin, Dept. of Obstetrics and Gynaecology, SLU, P.O. Box 7039, S-750 07 Uppsala, Sweden. E-mail: Anne-Marie Dalin@og.slu.se, tel. +46 (0) 18671948, fax +46 (0) 18 673545 . 